$3-1-2020$

\title{
To Serve and Protect: Examining the Relationship between Selling Alcohol in College Football Venues and Negative Fan Behaviors
}

\author{
Nels Popp \\ University of North Carolina at Chapel Hill, nelspopp@email.unc.edu \\ Archer Bane \\ Barton College \\ Steven Howell \\ Northern Illinois University \\ Barbara Osborne \\ University of North Carolina at Chapel Hill
}

Follow this and additional works at: https://trace.tennessee.edu/jasm

Part of the Education Commons, Social and Behavioral Sciences Commons, and the Sports Management Commons

\section{Recommended Citation}

Popp, Nels; Bane, Archer; Howell, Steven; and Osborne, Barbara (2020) "To Serve and Protect: Examining the Relationship between Selling Alcohol in College Football Venues and Negative Fan Behaviors," Journal of Applied Sport Management: Vol. 12 : Iss. 1.

https://doi.org/10.7290/jasm120106

Available at: https://trace.tennessee.edu/jasm/vol12/iss1/6

This article is brought to you freely and openly by Volunteer, Open-access, Library-hosted Journals (VOL Journals), published in partnership with The University of Tennessee (UT) University Libraries. This article has been accepted for inclusion in Journal of Applied Sport Management by an authorized editor. For more information, please visit https://trace.tennessee.edu/jasm. 


\title{
To Serve and Protect
}

\section{Examining the Relationship between Selling Alcohol in College Foot- ball Venues and Negative Fan Behaviors}

\author{
Nels Popp \\ Archer Bane \\ Steven M. Howell \\ Barbara Osborne
}

\begin{abstract}
Currently, many university and college athletics administrators are weighing the decision to sell alcoholic beverages at on-campus sporting events. Prior studies have found negative behaviors related to binge drinking spike on college campuses during football gamedays. However, empirical research examining the effect of a policy change regarding the selling of alcoholic beverages in college athletic venues on fan behavior remains somewhat limited. The current study examined longitudinal campus police records at 12 institutions which have recently changed their in-venue alcohol policy. Results from the analysis confirm prior studies suggesting negative behaviors increase on home football gamedays. The decision to sell alcohol within the campus football stadium, however, has no statistical impact on the rates of deviant behaviors recorded by campus police.
\end{abstract}

Keywords: Alcohol, drinking, collegiate football, university athletics

Nels Popp is an associate professor in the Department of Exercise and Sport Science at the University of North Carolina at Chapel Hill.

Archer Bane is the Executive Director of Institutional Advancement at Barton College.

Steven M. Howell is an associate professor in the Department of Kinesiology and Physical Education at Northern Illinois University.

Barbara Osborne is a professor in the Department of Exercise and Sport Science at the University of North Carolina at Chapel Hill.

Please send correspondence to Nels Popp, nelspopp@email.unc.edu 
While alcoholic beverages are sold at nearly all professional sporting events, college athletics departments and university administrators have been slow to allow the sale of alcohol within their on-campus venues. This decision stems from a variety of reasons including: (a) negative public perception, (b) state and local statutes limiting the ability to serve on campus, and (c) a fear that serving alcohol may lead to an increase in negative fan behavior. The number of universities allowing alcohol sales, however, continues to increase as many athletic departments have found the need to offset decreasing in-game attendance and create additional revenue streams (Dodd, 2016; Rovell, 2014). Since 2015, the number of NCAA Division I schools selling alcohol has increased from 34 (Malone, 2015) to 78 at the start of the 2019 season (Hayes, 2019). These include traditional, top-tiered programs and marquee, Power- 5 athletic conferences such as the Ohio State University (Myers, 2017), University of Texas (Cohen, 2017; Davis, 2016), and the Southeastern Conference (Sallee, 2019).

Prior research suggests sports fans consume alcohol more heavily than nonsports fans (Nelson \& Wechsler, 2003), fans consume more on gamedays (Glassman et al., 2010; Glassman et al., 2007; Leavens et al., 2019; Merlo et al., 2011; Neal \& Fromme, 2007), and increased levels of consumption on gamedays results in greater criminal activity (Lindo et al., 2018; Merlo et al., 2010; Rees \& Schnepel, 2009). Concurrently, many college athletics administrators believe allowing alcohol sales at sporting events may produce significant increases in revenues (Huang \& Dixon, 2013; Kimes, 2014; McDonald, 2020; Mitchell \& Montgomery, 2015; Myers, 2017; Murphy, 2015; WWL Staff, 2019). For example, in 2017, the Ohio State University athletic department reported generating made more than $\$ 1.2$ million in total net revenue from beer sales alone at Ohio Stadium (Myers, 2017). Despite this increase in revenue, the university also recorded 39 in-stadium arrests in 2017-an increase from the 22 occurring during the 2016 season. More recently, Louisiana State University's (LSU) Senior Athletic Direct, Robert Munson, reported that Tiger Stadium spectators made approximately 280,000 beer and wine purchases, resulting in more than $\$ 2.25$ million in net revenue for LSU's athletic department during the 2019 football season (McDonald, 2020; WWL Staff, 2019). Interestingly, however, previous research has yet to confirm that the availability of alcohol within the venue has a positive impact on gameday attendance (Augustin et al., 2018; Chastain et al., 2017).

Although growing, there remains a dearth of empirical research exploring the relationship between fan behavior and crime with policy changes allowing alcohol sales at collegiate sport venues (Barry et al., 2019; Howell et al., 2015; Menaker \& Sheptak Jr., 2018). Therefore, the primary objective of the present study is to investigate changes in levels of deviant behaviors and alcohol-related incidents during gamedays at universities which allow alcohol sales at their on-campus football venues. More specifically, the study examines a sample of universities which have recently changed their policy affording a pre- and postpolicy comparison of behaviors. 


\section{Alcohol Usage on College Football Game Days}

Alcohol consumption tends to spike among college students surrounding key events such as birthdays, holidays, and major campus sporting events (Glassman et al., 2010; Neal et al., 2005; Neighbors et al., 2011; Woodyard \& Hallam, 2010). In fact, increased drinking has been positively correlated to the quality of football opponents particularly on the home campus (Barry et al., 2014; Menaker \& Chaney, 2014; Neal \& Fromme, 2007). Additionally, nonstudents attending college football games are also more likely to consume alcohol (Barry et al., 2014; Glassman et al., 2011; Haun et al., 2007), many times at dangerously high levels (Glassman et al., 2010; Glassman, et al., 2007; Merlo et al., 2011; Neal \& Fromme, 2007). Researchers have also found a spike in alcohol-related deviant behaviors on college football gamedays (Barry et al., 2019; Lindo et al., 2018; Merlo et al., 2010; Rees \& Schnepel, 2009). For example, college-aged rape incidences were reported at a $41 \%$ higher rate, and disorderly conduct, DUI, and liquor law violations went up $80 \%$, on days of home college football games (Lindo et al., 2018).

Little research has explored the impacts of a change in stadium policy related to selling alcohol and conclusions from those studies have been mixed. In 1996, for example, the University of Colorado at Boulder eliminated alcohol sales at football games, resulting in a decrease in security incidents during the next season (Bormann \& Stone, 2001). Vingilis et al. (1992) found post-game DUI arrests near the ballpark did not significantly increase when Major League Baseball's Toronto Blue Jays began serving alcohol at home contests. More recently, Howell et al. (2015) analyzed in-venue alcohol-related incidents for 20 home football contests over three seasons at a single university, which included a change in policy during the years examined and found during the two years in which alcohol was prohibited, more alcohol-related incidents occurred than in the year in which it was allowed. When comparing reported crime and stadium ejection rates at college football stadia, Menaker and Chaney (2015) found a statistically significant relationship between a university's alcohol sales policy and game-day reports of criminal behavior. Further research has found game start time and opponent quality predicts increases of alcohol-related ejections from college football stadiums (Menaker et al., 2018). Most recently, in a case study examination of one Power Five university, Barry and colleagues (2019) saw a general upward trend in crime incidents on gameday weekends after an in-venue alcohol policy was implemented.

To our knowledge, however, no comprehensive study has investigated deviant fan behavior data at multiple institutions in which there has been a change in alcohol policy, despite calls to do so (Barry et al., 2019; Chastain et al., 2017). As a result, the purpose of the current study is to compare measures of negative fan behavior before and after a change in alcohol sales policy at on-campus college football venues. Specifically, the study examines two research questions: $\left(\mathrm{RQ}_{1}\right)$ whether differences in criminal offenses and alcohol-related incidents exist between collegiate football gamedays compared to non-gamedays; and $\left(\mathrm{RQ}_{2}\right)$ 
whether differences in criminal offenses, alcohol-related incidents, and in-stadium offenses exist between gamedays before and after a policy change to sell alcohol in-venue.

\section{Methodology}

University campus police crime data were requested from schools in which alcohol is sold at an on-campus football stadium. At the time of data collection, 23 universities were identified as selling alcohol within on-campus football stadia (several other schools which sold alcohol play home games off campus, typically in a National Football League venue). Citing the Cleary Act, campus crime log data were requested from those universities for three years prior to and three years after allowing alcohol sales at their on-campus venues. Twelve schools, located in eight different states, provided timely and relevant data. Mean undergraduate enrollment for these institutions was approximately 20,000 students (range $=6,500$ to 31,000 students). Four of the schools participated in a Power Five conference, while eight participated in a Group of Five conference. The mean population of the city in which the university resides for the sample was 301,789 (range $=30,955$ to $1,345,000)$ and the mean MSA population for the schools in the sample was $2,445,046$ (range $=139,044$ to $7,573,136$ ).

Once crime logs were acquired, the researchers collected the dates of home football games for three years prior and three years after a change in alcohol sales policy. For every game date selected, another fall non-gameday Saturday was selected. In all, a total of 400 game dates and 400 non-game dates were identified. The crime logs for these 800 dates contained a total of 4,905 criminal offenses and 2,352 alcohol-related incidents. Campus crime logs were analyzed and incidents were categorized into three subgroups: (a) campus criminal offenses, (b) campus alcohol related incidents, and (c) in-stadium criminal offenses.

A paired samples $t$-test was conducted to compare rates of criminal offenses and alcohol-related incidents between gameday Saturdays and non-gameday Saturdays $\left(\mathrm{RQ}_{1}\right)$. Next, paired samples $t$-tests were conducted to compare the rate of: (a) gameday criminal offenses, (b) gameday alcohol-related incidents, and (c) in-stadium criminal offenses before and after the decision to sell alcohol in-venue $\left(\mathrm{RQ}_{2}\right)$. The significance cutoff for all statistical tests was set at the .05-level.

\section{Results}

To address $\mathrm{RQ}_{1}$, a paired samples $t$-test was conducted to compare both criminal offenses and alcohol-related incidents between gamedays and non-gamedays. Reported criminal offenses were significantly higher on gamedays $(M=7.7, S D$ $=4.6)$ than on non-gamedays $[M=4.6, S D=2.8 ; t(11)=-3.259, p=.008]$, while reported alcohol-related incidents were also significantly higher on gamedays $(M$ $=4.0, S D=3.3)$ than on non-gamedays $[M=2.0, S D=1.5 ; t(11)=-2.831, p=.016]$.

To address $R_{2}$, the researchers used the mean number of crime log entries for the three years pre-alcohol selling policy, which eliminated two of the univer- 
sities in the sample. Conducting paired samples $t$-tests, mean scores were tested against the number of crime log entries the first, second, and third years after selling, as well as the three-year average after selling. The full results, including $\mathrm{p}$ values and mean scores, can be found in Table 1. In all cases, crime log entry mean scores decreased post-alcohol sales policy; however, the mean differences were not statistically significant.

\section{Discussion and Implications}

Currently many college athletics departments and university administrators are considering or have altered their policy on the sale of alcoholic beverages at their on-campus athletics facilities. While these endeavors may yield additional financial returns (Cohen, 2017; Davis, 2016; McDonald, 2020; Myers, 2017; WWL Staff, 2019) such decisions carry significant consequences in terms of public perception, legal liability, and spectator safety (Myers, 2017). To date, administrators and university stakeholders have little empirical findings to assist with this specific decision-making process. As a result, the present study provides some quantitative context by exploring deviant behavior trends surrounding college football home games in which alcohol is available for sale.

The first research question posited whether deviant behavior increases on college football gamedays on campuses where alcohol is served in-venue. Echoing previous research findings (Barry et al., 2019; Lindo et al., 2018; Merlo et al., 2010; Rees \& Schnepel, 2009), study findings suggest significantly more negative behaviors are registered by campus police on college gamedays compared to nongameday Saturdays. College football gamedays at FBS schools tend to be major events and bring large numbers of visitors to a campus. This increase in numbers could explain some of the difference in campus police activity. Excessive drinking by both students and non-student fans on college gamedays may also contribute to the uptick in reported incidents. While the purpose of the study was not to determine the cause of changes in number of incidents, the present findings support prior research suggesting college football gamedays produce a greater number of negative behavior incidents, both in general crimes and alcohol-related negative behaviors, on campus (e.g., Barry et al., 2019; Menaker \& Sheptak, Jr., 2018).

The focus of the second research question was whether the availability of alcohol for sale within college football stadia has an impact on the number of negative incidents recorded by campus police compared to the same venue prior to the introduction of alcohol sales. The results point to a reduction in negative behaviors when alcohol is sold, which is counter to the findings of Barry and colleagues (2019). Three different measures were utilized to test the effects; number of recorded gameday criminal offenses, number of recorded gameday alcohol-related incidents, and number of recorded in-stadium criminal offenses. For all three categories, the mean number of incidents actually decreased. For a small number of individual schools, criminal and negative behavior did increase slightly after the introduction of alcohol sales, but for the schools with the most total incidents, 
Selling Alcohol in College Football Venues and Negative Fan Behaviors

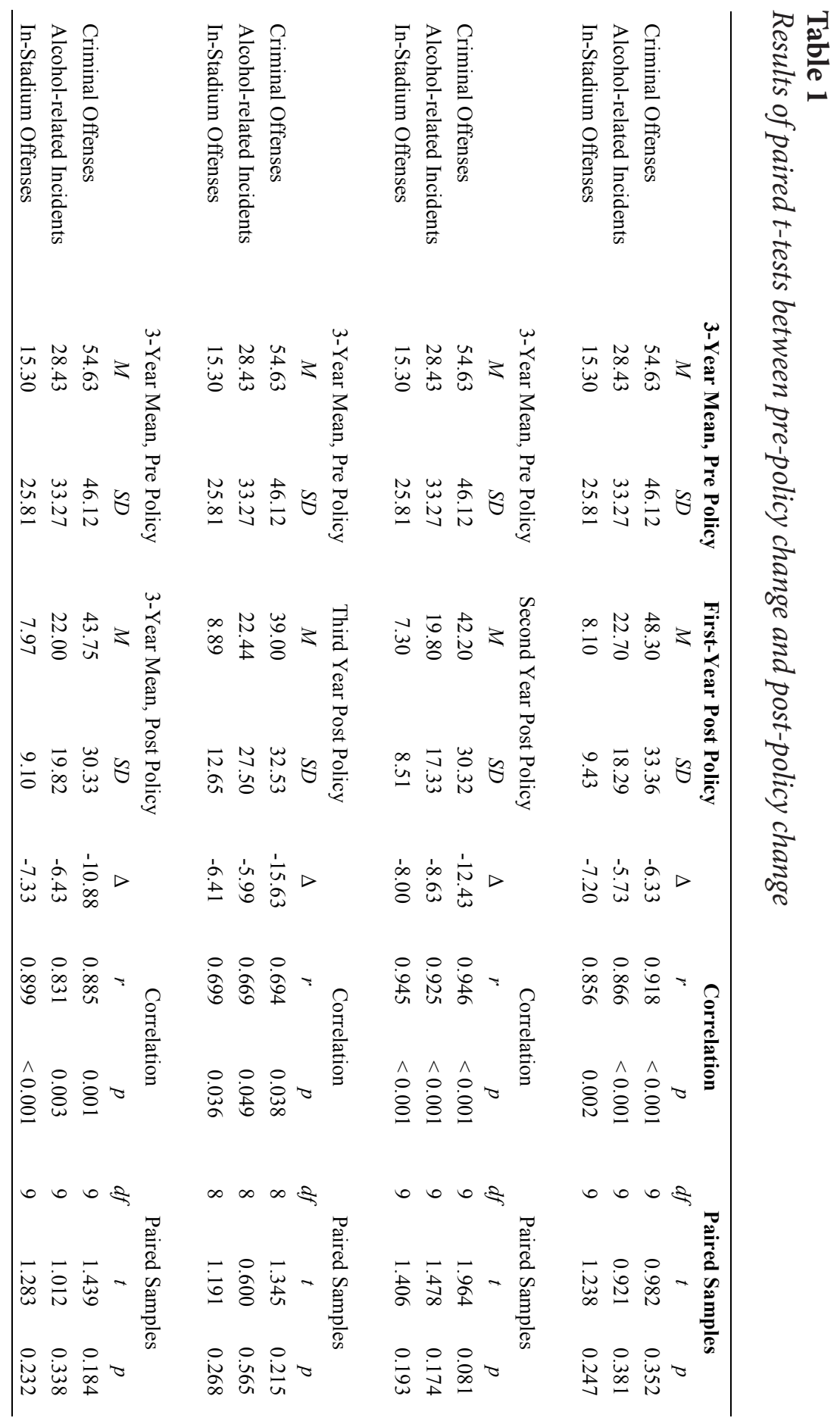


recorded negative behavior lowered considerably. Overall, averages went down across all institutions.

Several explanations exist as to why these differences emerged. First, schools introducing in-venue alcohol sales are also likely to increase security and safety measures accompanying the decision. For example, Ohio State reported the additional revenue generated through alcohol sales was directed toward funding four additional university police officer positions, increased security, and other campus safety initiatives (Myers, 2017). Second, by adding the availability of alcohol within the venue, spectators may reduce the amount they drink outside the venue because they are now able to maintain an alcohol-related "buzz" in the venue by purchasing beverages. This could reduce binge drinking immediately prior to entering the stadium (Glassman et al., 2010; Glassman et al, 2007; Leavens et al., 2019; Merlo et al., 2011; Neal \& Fromme, 2007). Third, alcohol sold within the venue is more cost prohibitive (and can only be purchased in lower quantities (i.e., limiting patrons to the purchase of one or two beverages at a time).

Despite providing new findings on the impact of alcohol sales at college football venues, the present study is not without its own limitations. First, the analysis was limited to only $12 \mathrm{D} 1$ universities, when currently $78 \mathrm{D} 1$ institutions serve alcohol in some capacity within their football venues. Additionally, only four of these schools were members of a Power Five conference, while the other eight were members in a Group of Five conference. Future research should endeavor to examine a larger sample of universities over a more extended period of time. Further work in this area would benefit university administration, college athletic departments, and campus/local law enforcement agencies. Finally, future research should also assess the impact of newly formed initiatives surrounding alcohol sales, such as increased gameday security presence and campus social media campaigns. Exploration of these issues will provide local officials and university administrators the most complete information when deciding on the extent to which to allow alcohol sales their respective athletic and campus venues.

While university and athletic administrators continue to introduce alcohol sales at their athletic events, the associated health and social risks should not be overlooked (Nietzel, 2018). As a result, continued research in this area is warranted to provide a better understanding of these issues as these discussions progress. Ultimately, it is important that university administrators, athletic departments, public health officials, and local law enforcement agencies work collaboratively to assess the potential benefits of increased financial gains against the cost of increased alcohol-related behavior.

\section{References}

Augustin, J. D., Traugutt, A., \& Morse, A. (2018). The effects of beer sales on attendance at collegiate football games. The Journal of SPORT, 6(1). https://oaks. kent.edu/sport/vol6/iss1/effects-beer-sales-attendance-collegiate-footballgames 
Barry, A. E., Howell, S., Bopp, T., Stellefson, M., Chaney, E., Piazza-Gardner, A., \& Payne-Purvis, C. (2014). A field-based community assessment of intoxication levels across college football weekends: Does it matter who's playing? Journal of Primary Prevention, 35(6), 409-416.

Barry, A. E., Howell, S. M., \& Salaga, S. (2015). Tapping into alcohol sales at college football stadiums: The need for research examining the policy's impact on drinking behaviors and associated incidents. Journal of Alcohol and Drug Education, 59(2), 7-11.

Barry, A. E., Russell, A., Howell, S., Phan, P., Reyes, D. \& Bopp, T. (2019). (Unintended) consequences of initiating an alcohol sales policy at college football stadiums: A case study. Journal of American College Health, 67(5), 397-401.

Bormann, C. A., \& Stone, M. H. (2001). The effects of eliminating alcohol in a college stadium: The Folsom beer ban. Journal of American College Health, 50(2), 81-88.

Chastain, A. J., Gohmann, S. F., \& Stephenson, E. F. (2017). Beer availability and college football attendance: Evidence from mid-major conferences. Journal of Sports Economics, 18(6), 592-600.

Cohen, B. (2017, January 08). College football: Beer sales are bigger in Texas. https://www.wsj.com/articles/college-football-beer-sales-are-bigger-in-texas- 1483904806

Davis, B. (2016, December 20). Texas fans drink up; Alcohol sales jumped more than 70 percent in 2016. https://www.hookem.com/story/texas-fans-drinkalcohol-salesjumped-70-percent-2016/

Dodd, D. (2016, June 17). Alcohol: Coming soon to a college football stadium near you. https://www.cbssports.com/collegefootball/news/alcohol-coming-soonto-your-collegefootball-stadium-if-its-not-there-already/

Glassman, T., Braun, R., Reindl, D.M., \& Whewell, A. (2011). Blood (breath) alcohol concentration rates of college football fans on gameday. Journal of Alcohol and Drug Education, 55(2), 55-73.

Glassman, T. J., Dodd, V. J., Sheu, J., Rienzo, B. A., \& Wagenaar, A. C. (2010). Extreme ritualistic alcohol consumption among college students on gameday. Journal of American College Health, 58(5), 413-423.

Glassman, T., Werch, C. E., Jobli, E., \& Bian, H. (2007). Alcohol-related fan behavior on college football gameday. Journal of American College Health, 56(3), 255-260.

Haun, J., Glassman, T., Dodd, V. J., \& Young, G. C. D. (2007). Game-day survey results: Looking at football fan alcohol-related behaviors. American Journal of Health Education, 38(2), 91-96.

Hayes, D. (2019, November 19). College football programs that sell in-stadium beer \& alcohol at games in 2019 NCAAF season. https://www.fanduel.com/ theduel/posts/college-football-programs-that-sell-in-stadium-beer-alcoholat-games-in-2019-ncaaf-season-01dje257jj5d 
Huang, K., \& Dixon, M. A. (2013). Examining the financial impact of alcohol sales on football gamedays: A case study of a major football program. Journal of Sport Management, 27(3), 207-216.

Kimes, M. (2014, October 14). Beer moving inside college stadiums. https://www. espn.com/college-sports/story/_/id/11827038/southern-methodist-latestsell-beer-college-stadiums

Leavens, E. L. S., Croff, J., Feddor, R., \& Olson, K. (2019). It's game time: Drinking intentions, alcohol consumption, and consequences at college tailgates. Substance Use and Misuse, 54(1), 11-17.

Lindo, J. M., Siminski, P., \& Swensen, I. D. (2018). College party culture and sexual assault. American Economic Journal: Applied Economics, 10(1), 236-265.

Malone, C. (2015, October 16). Beer map shows list of college stadiums selling alcohol. http://www.saturdaydownsouth.com/sec-football/beer-map-showstrend-stadiums-selling-beer/

McDonald, S. (2020, January 6). LSU Football shined in 2019, but its fans glowed with alcohol sales across the south this season. https://www.newsweek.com/ lsu-football-shined-2019-its-fans-glowed-alcohol-sales-across-south-thisseason- 1480703

Menaker, B., Barry, A. E., \& Howell, S. M. (2018). Identifying the influence of opponent ranking and game characteristics on alcohol-related stadium ejections. Journal of Primary Prevention, 39(2), 117-128.

Menaker, B. E., \& Chaney, B. H. (2014). College football gameday stadium incidents: Policy and environmental effects on alcohol-related ejections and crime. Journal of Policy Research in Tourism, Leisure and Events, 6(2), 119-134.

Menaker, B. E., \& Sheptak Jr., R. D. (2018). The impact of game day on crime on a university police department: Application of the civilizing process to sportrelated law enforcement. Journal of Policy Research in Tourism, Leisure and Events. Leisure and Events, 12(2), 172-184.

Merlo, L. J., Hong, J., \& Cottler, L. B. (2010). The association between alcoholrelated arrests and college football gamedays. Drug and Alcohol Dependence, 106(1), 69-71.

Merlo, L. J., Ahmedani, B. K., Barondess, D. A., Bohnert, K. M., \& Gold, M. S. (2011). Alcohol consumption associated with collegiate American football pre-game festivities. Drug and Alcohol Dependence, 116(1-3), 242-245.

Mitchell, M., \& Montgomery, R. D. (2015). Beer and ball on campus? The issue of in-stadium alcohol sales. http://thesportjournal.org/article/beerand-ball-on-campus-the-issue-of-in-stadium-alcohol-sales/

Murphy, M. K. (2015, January 29). More fun for fans. http://www.athleticmanagement.com/2013/05/26/more_fun_for_fans/index.php

Myers, J. (2017, December 11). Ohio State profits $\$ 1.23$ million from stadium alcohol sales, increase in stadium arrests. https://www.thelantern.com/2017/12/ ohio-state-profits-1-35-million-from-stadium-alcohol-sales-increase-in-stadium-arrests/ 
Neal, D. J., \& Fromme, K. (2007). Hook'em horns and heavy drinking: Alcohol use and collegiate sports. Addictive Behaviors, 32, 2681-2693.

Neal, D. J., Sugarman, D.E., Hustad, J. T. P., Caska, C. M., \& Carey, K. B. (2005) It's all fun and games...or is it? Collegiate sporting events and celebratory drinking. Journal of Studies on Alcohol, 66(2), 291-294.

Neighbors, C., Atkins, D. C., Lewis, M. A., Lee, C. M., Kaysen, D., Mittmann, A., Rodriguez, L. M. (2011). Event specific drinking among college students. Psychology of Addictive Behaviors, 25(4), 702-707.

Nelson, T. F., \& Wechsler, H. (2003). School spirits: Alcohol and collegiate sport fans. Addictive Behaviors, 28(1), 1-11.

Nietzel, M.T. (2018, December 1). Sobering thoughts about alcohol sales at college stadiums. https://www.forbes.com/sites/michaeltnietzel/2018/12/01/secondsobering-thoughts-about-alcohol-sales-at-college-stadiums/

Rees, D. I., \& Schnepel, K. T. (2009). College football games and crime. Journal of Sports Economics, 10(1), 68-87.

Rovell D. (2014, February 17). Will next generation of fans show up? http:// www. espn.com/college football/story/_/id/10458047/ next-generation-ticket-holder-concern-students-showcollege-football-games

Sallee, B. (2019, May 31). SEC lifts ban on alcohol sales, allows schools to decide on selling beer and wine at on-campus venues. https://www.cbssports.com/college-football/news/sec-lifts-ban-on-alcohol-sales-allows-schools-to-decideon-selling-beer-and-wine-at-on-campus-venues/

Vingilis, E., Liban, C. B., Blefgen, H., Colbourne, D., \& Reynolds, D. (1992). Introducing beer sales at a Canadian ball park: The effect of motor vehicle accidents. Accident Analysis and Prevention, 24(5), 521-526.

Woodyard, C.D., \& Hallam, J. S. (2010). Differences in college student typical drinking and celebration drinking. Journal of American College Health, 58(6), 533-538.

WWL Staff. (2019, December 6). LSU's Tiger Stadium sold $\$ 2$ million in drinks after alcohol policy change. https://www.wwltv.com/article/sports/ncaa/lsu/lsu-tiger-stadium-sold-2m-in-drinks-after-alcohol-policy-change/289-1a20313aeb16-4738-b495-c05a15bdc7ae 